\title{
Sistem Informasi Geografis Potensi Sumber Daya Kelautan Berbasis Android
}

\author{
Pratyaksa Ocsa Nugraha Saian ${ }^{1}$, Raka Arya Pratama ${ }^{2}$, Yerymia Alfa Susetyo ${ }^{3}$ \\ ${ }^{1}$ Fakultas Teknologi Informasi, Universitas Kristen Satya Wacana \\ Jalan Dr. O Notohamidjojo 1-10, Kelurahan Blotongan, Kecamatan Sidorejo, Salatiga 50715, e- \\ mail: pratyaksa.ocsa@uksw.edu \\ ${ }^{2}$ Fakultas Teknologi Informasi, Universitas Kristen Satya Wacana \\ Jalan Dr. O Notohamidjojo 1-10, Kelurahan Blotongan, Kecamatan Sidorejo, Salatiga 50715, e- \\ mail:672014140@student.uksw.edu \\ ${ }^{3}$ Fakultas Teknologi Informasi, Universitas Kristen Satya Wacana \\ Jalan Dr. O Notohamidjojo 1-10, Kelurahan Blotongan, Kecamatan Sidorejo, Salatiga 50715, e- \\ mail: yeremia.alfa@uksw.edu
}

\section{ARTICLE INFO}

Article history:

Received 25 August 2020

Received in revised form 01 December

2020

Accepted 22 December 2020

Available online 31 January 2021

\begin{abstract}
Indonesia is the biggest maritime country that has big marine resources too. It needed a good strategy so the marine resource usage can be managed well. Now, it can be helped by using information technology. The purpose of this research is to create a Geographic Information System for knowing potential marine resources in Daerah Istimewa Yogyakarta Coast. Geographic Information System was chosen because it can run well in Android devices by using a Google Map API which is already provided by Google itself. Also, by implement it in Android makes the application have great mobility and makes it easier to be accessed by users. The result of this paper is a Geographic Information System that will runs on Android devices. The test results show $82,93 \%$ of users already satisfied with this application. It indicates that this application is in a "Very Good" category.
\end{abstract}

Keywords: Android; Agile Software Development; Geographic Information System; Google Map API; Marine Resources

\section{Pendahuluan}

Luas total wilayah Indonesia adalah $7,81 \mathrm{~km}^{2}$ yang terdiri dari $2,01 \mathrm{~km}^{2}$ adalah daratan, $3,25 \mathrm{~km}^{2}$ adalah lautan dan sisanya adalah Zona Ekonomi Eksklusif [1]. Lebih luasnya lautan Indonesia dibandingkan dengan daratan menyebabkan Indonesia sering juga disebut sebagai negara kepulauan atau negara maritim. Oleh karena itu, Indonesia saat ini merupakan negara dengan potensi sumber daya kelautan yang sangat besar. Saat ini, kekayaan sumber daya kelautan Indonesia diperkirakan sekitar US\$ 136,5 milyar yang terdiri dari: wisata US\$ 2 milyar, migas US\$ 6,6 milyar, perikanan US\$31,9 milyar, bioteknologi US\$ 40,0 milyar, dan pesisir lestari US\$ 56,0 milyar [2].

Agar pembahasan tidak terlalu luas, penelitian ini akan fokus membahas tentang wilayah Pesisir Pantai Selatan Daerah Istimewa Yogyakarta (DIY). Secara geografis, bagian selatan DIY berbatasan langsung dengan Samudera Hindia yang menyebabkan wilayah selatan sebagian besar adalah garis pantai. Panjang garis pantai ini membentang sepanjang 61,02 mil yang melewati tiga wilayah Kabupaten, yaitu Bantul, Kulon Progo dan Gunung Kidul. Beberapa sumber daya kelautan utama bagi penduduk di wilayah pesisir antara lain: ikan pelagis besar, udang, lobster. Tidak hanya itu, dari sisi pariwisata juga memiliki dampak yang cukup signifikan seperti: 
terumbu karang dan jasa lingkungan. Hal ini berdampak bahwa daerah tersebut merupakan tempat yang menguntungkan dalam bidang perdagangan lingkup lokal hingga lingkup internasional [3].

Meskipun saat ini beberapa sumber daya kelautan sudah terkelola dengan baik, tetapi masih memungkinkan untuk ditingkatkan lagi. Keberadaan teknologi informasi saat ini dapat dimanfaatkan untuk menciptakan keberlangsungan pemanfaatan sumber daya kelautan yang lebih panjang. Hal ini diharapkan mampu membuat pemerintah atau pelaku usaha untuk memanfaatkan sumber daya kelautan agar menjadi sebuah komoditas andalan [4].

Masalah yang dihadapi saat ini adalah keterbatasan akses dalam mencari informasi terkait dengan persebaran sumber daya yang terdapat pada wilayah pesisir Pantai Selatan DIY. Pemerintah juga sulit untuk mengklasifikasikan beberapa sumber daya yang ada, berikut dengan ketidaksesuaian data yang diperoleh dengan situasi aktual di lapangan. Dari sisi masyarakat, mereka tidak dapat menjangkau seluruh informasi yang tersedia secara akurat terkait dengan sumber daya kelautan dan potensi yang tersedia di Pesisir Pantai Selatan. Sejauh ini hanya ada sebuah halaman web yang menyediakan informasi tentang sumber daya kelautan, namun masih belum maksimal digunakan karena data yang diperoleh tidak akurat.

Berdasarkan latar belakang yang ada, masih diperlukannya sebuah sistem informasi yang akan memberikan informasi tentang potensi sumber daya kelautan yang dimiliki oleh Pesisir Pantai Selatan DIY lebih lengkap lagi. Sistem Informasi Geografis (SIG) merupakan salah satu solusi yang bisa digunakan untuk menyelesaikan masalah tersebut. Dibuatnya SIG akan membantu pengguna untuk mendapatkan informasi yang lebih lengkap dan lebih akurat jika dibandingkan dengan sebuah halaman web saja. Terlebih lagi jika SIG ini dibuat dengan menggunakan Google Map API. Selain kemudahan dalam proses integrasi dengan sistem Android, Google Map API juga memiliki fitur yang lengkap.

Penelitian ini akan merancang sebuah SIG berbasis Android dengan memanfaatkan Google Map API. Pemilihan Android pada pembuatan SIG ini didasari pada jumlah pengguna Android yang terus bertambah dari tahun 2011 sampai sekarang [5]. Hal ini menyebabkan semakin besarnya peluang untuk SIG ini dapat digunakan oleh pengguna nantinya. Diterapkannya SIG ke dalam Android juga akan menambah mobilitas aplikasi sehingga aplikasi akan semakin mudah untuk diakses.

\section{Kajian Pustaka}

Secara garis besar, penelitian ini adalah penelitian lanjutan dari penelitian sebelumnya. Penelitian sebelumnya fokus membahas tentang pembangunan SIG dalam bentuk web, sedangkan pada penelitian ini lebih fokus terhadap SIG dalam bentuk Android [6]. Selain itu, masih ada beberapa penelitian yang berhubungan dengan penerapan SIG dalam berbagai bidang atau penggunaan Google Map API. Beberapa penelitian itu adalah:

Penelitian yang berjudul "Sistem Informasi Geografis Sebaran Tempat Riset Teknologi Informasi di Kota Garut" membahas bahwa sebuah SIG dapat digunakan untuk memastikan persebaran atau letak dari sebuah objek. Pada penelitian ini, SIG yang dibuat dapat memetakan bagaimana persebaran tempat-tempat yang telah dijadikan tempat riset. Tidak hanya itu, SIG yang dibuat juga mampu memberikan pelaporan sebagai luaran akhir yang menjadikan SIG ini menjadi dasar dalam melakukan riset. Secara umum, tujuan utama pembuatan SIG ini adalah memberikan informasi kepada pihak kampus berupa sebaran tempat serta informasi aktivitas penelitian yang dilakukan mahasiswanya [7].

Penelitian lain terkait SIG dan Android berjudul "Rancang Bangun Sistem Informasi Geografis Persebaran Lokasi Obyek Pariwisata Berbasis Web dan Mobile Android dengan Contoh Kasus: Kabupaten Gianyar, Bali”. Sistem informasi ini dibuat dalam dua bentuk, yaitu halaman web dan Android. Kedua sistem informasi ini akan memberikan informasi terkait semua obyek wisata di Kabupaten Gianyar, Bali. Penggunaan pointer pada navigasi juga mendukung sebuah sistem informasi geografis di mana semua informasi yang terkait dapat diakses dengan mudah dan tepat oleh pengguna. Selebihnya, fungsi dari sistem informasi geografis ini akan 
memudahkan pengguna/wisatawan ketika mencari informasi obyek dan lokasi wisata di Kabupaten Gianyar, Bali [8].

Penelitian lain berjudul "Implementasi Sistem Informasi Geografis menggunakan Google Map API dalam Pemetaan Asal Mahasiswa". Penelitian ini membahas bahwa pemanfaatan Google Map API menunjukkan bahwa eksistensi sebuah fakultas dalam sebuah daerah masih terbatas. Agar pemanfaatannya dapat maksimal, dibutuhkan sebuah pemahaman dan juga perluasan informasi dengan sebuah SIG. Menggunakan Google Map API ini akan membantu mengetahui letak geografis asal mahasiswa yang mengikuti perkuliahan di sebuah fakultas. Informasi yang diberikan oleh sistem adalah gambaran dari mana asal mahasiswa sehingga pihak kampus bisa mengetahui persebaran wilayah dari masyarakat yang mengenal kampus terkait [9].

Penelitian lain yang berjudul "Pemanfaatan Google Map API untuk Pembangunan Sistem Informasi Manajemen Bantuan Logistik Pasca Bencana Alam Berbasis Mobile Web". Penelitian ini membahas tentang sebuah sistem informasi yang dapat memberikan informasi terkait bantuan bencana alam. Informasi yang diberikan dapat berupa jarak, rute jalan, penunjuk arah jalan, serta daftar kebutuhan logistik. Tidak hanya itu, sistem informasi yang dibangun juga dapat membantu pengelolaan logistik di pos komando [10].

Berdasarkan penelitian terdahulu terkait dengan SIG serta penggunaan Google Map API, penelitian tentang SIG Potensi Sumber Daya Kelautan ini dilakukan. Pemanfaatan Google Map API berdasarkan penelitian terdahulu didasari oleh kemampuan dan fasilitas yang diberikan dapat memaksimalkan penyebaran informasi yang akurat. Selain itu, Google Map API juga mempersiapkan sebuah platform mobile yang dapat digunakan dengan mudah dan efektif khususnya ketika diterapkan ke dalam Android.

Selain perbedaan kasus yang diteliti, perbedaan lainnya adalah jumlah informasi yang disediakan. Seperti yang sudah dijelaskan sebelumnya, penggabungan aplikasi web yang telah dibuat sebelumnya dengan penelitian ini akan memperkaya informasi yang diberikan. Ditambah lagi dengan sifat dasar Android yang memiliki mobilitas tinggi, maka informasi yang disediakan dapat dengan mudah diakses oleh siapa saja.

Penelitian ini diharapkan mampu membantu masyarakat daerah pesisir Pantai Selatan berikut dengan instansi pemerintah terkait agar mampu memaksimalkan sumber daya alam kelautannya. Penelitian ini diharapkan dapat mengembangkan sekaligus memaksimalkan data berupa sumber daya kelautan dalam pemanfaatannya di daerah Pesisir Pantai Selatan DIY serta memungkinkan dalam pengembangan aplikasi lintas platform.

\subsection{Android}

Android merupakan salah satu dari sebuah sistem operasi yang dibuat secara khusus untuk perangkat-perangkat yang menggunakan teknologi touchscreen. Sistem operasi Android termasuk dalam sistem operasi yang bersifat open source karena menggunakan kernel Linux di dalamnya. Oleh karena itu, banyak sekali perusahaan teknologi besar yang mengembangkan Android versi mereka sendiri. Perusahaan-perusahaan seperti Samsung, Sony, Mi, HTC, LG, Lenovo, Vivo, Oppo sudah mengembangkan Android dengan fitur-fitur yang disesuaikan dengan kebutuhan perusahaan masing-masing.

Pesatnya pertumbuhan Android selain karena faktor open source yang dimilikinya, juga karena Google sebagai pembuat utama Android, memiliki marketplace yang sudah besar. Google Play Store adalah layanan penyedia aplikasi Android yang sangat mudah diakses oleh para pengembang aplikasi. Ini membuat para pengembang berlomba-lomba untuk menciptakan aplikasi yang baik dan bisa laku di sana. Hal ini menyebabkan Android terus berkembang pesat baik dari segi teknologi maupun dari segi jumlah device di seluruh dunia [11].

\subsection{Google Map API}

Secara umum, Application Programming Interface (API) dapat disebut sebagai jembatan dari suatu aplikasi dengan aplikasi lainnya. API biasanya terdiri dari fungsi-fungsi yang telah disediakan dan sudah siap untuk digunakan oleh pengembang selanjutnya. Begitu juga dengan Google Map API. Google Map API merupakan API buatan Google yang bertujuan untuk 
memudahkan pengembang mengintegrasikan layanan Google Map ke dalam halaman web atau aplikasi Android masing-masing.

Sebelum dapat digunakan, Google Map API membutuhkan sebuah kunci yang digunakan server Google untuk melakukan proses validasi dari setiap permintaan yang dilakukan. Kunci ini atau sering juga disebut API Key, merupakan sebuah kode unik yang didapatkan dari Google dengan mendaftarkan akun sebagai pengembang aplikasi [12].

\subsection{Sistem Informasi Geografi}

Sistem Informasi Geografi (SIG) adalah sebuah sistem informasi yang mampu untuk mengolah data-data yang berkaitan dengan geografis dan menampilkannya sebagai sebuah informasi spasial. Kemajuan teknologi saat ini juga menyebabkan berkembangnya SIG karena SIG saat ini dapat dikombinasikan dengan database sebagai tempat penyimpanan data.

Pembangunan sebuah SIG biasanya menerapkan sebuah konsep yang bernama Real World. Secara garis besar, konsep ini akan memodelkan apa yang ada di dalam dunia nyata ke dalam sistem yang dibangun. Konsep ini memiliki lima tahap utama, yaitu 1) Physical Reality yang merupakan proses analisa dari objek di dunia nyata yang akan digunakan ke dalam sistem; 2) Real World Model yang merupakan proses mengubah objek di dunia nyata menjadi sebuah model; 3) Data Model yang merupakan proses perubahan dari model menjadi tipe data yang dimengerti sistem; 4) Database padahal proses penyimpanan semua model ke dalam sistem; 5) Maps/Reports adalah proses penyajian data yang umumnya dalam bentuk peta [13].

Proses pencarian dan pengumpulan data terkait SIG pada penelitian ini dilakukan dengan langsung mendatangi tempat-tempat strategis yang dianggap sebagai penghasil sumber daya alam kelautan. Selain itu, dilakukan juga wawancara langsung dengan para pelaku bisnis maupun warga di sekitar daerah tersebut. Data yang telah terkumpul nantinya akan diolah lebih lanjut untuk dimodelkan ke dalam bentuk penanda (marker) di dalam peta.

\subsection{Arsitektur Sistem}

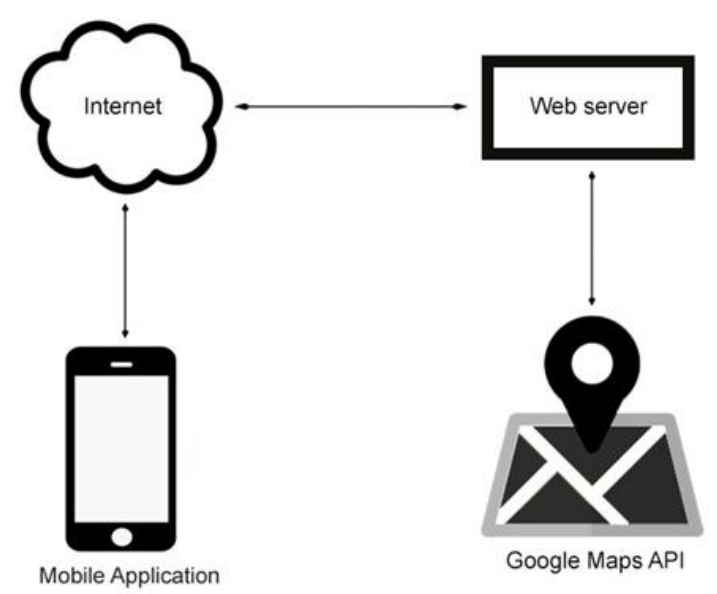

Gambar 1 Arsitektur Sistem

Gambar 1 menjelaskan bagaimana rancangan arsitektur sistem yang dibangun. Terdapat empat komponen utama di dalam SIG yang akan dibangun, yaitu: a) Aplikasi Android; b) Internet; c) Web Server; dan d) Google Map API. Keempat komponen ini harus terhubung sehingga proses pengiriman maupun penerimaan data dapat terjalin dengan baik.

Sistem ini akan bekerja diawali dari pengguna yang menggunakan Android akan mengirimkan sebuah permintaan melalui internet ke web server. Setelah itu, web server akan melanjutkan permintaan ke server milik Google melalui Google Map API. Permintaan ini dibaca dan diterjemahkan oleh server Google, kemudian dikembalikan ke web server. Web server mengolah datanya kembali, sebelum akhirnya ditampilkan lagi di aplikasi Android. Proses ini akan terus terjadi selama pengguna masih menggunakan aplikasi. 


\section{Metodologi Penelitian}

Penelitian ini akan menggunakan metode Agile Software Development. Agile Software Development adalah sebuah metodologi pengembangan perangkat lunak yang menerapkan konsep iterasi di dalamnya. Konsep iterasi ini biasanya terjadi karena pada dasarnya Agile Software Development sangat mengedepankan kepuasan pelanggan. Oleh karena itu, ketika ada perubahan-perubahan yang diminta pelanggan atau perubahan yang harus terjadi ketika proses pembuatan perangkat lunak akan segera teratasi [14], [15].

Tahapan penelitian yang akan digunakan dalam Pembangunan SIG Potensi Sumber Daya Kelautan ini digambarkan di Gambar 2.

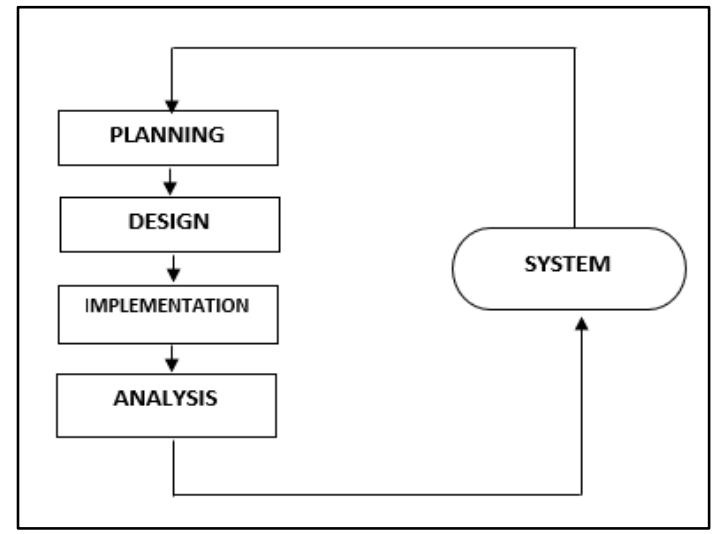

Gambar 2 Metode Agile Software Development

Tahap awal adalah Planning. Tahap ini berfokus pada pengumpulan data. Terdapat tiga jenis data utama yang diperlukan, yaitu: data tentang sumber daya perikanan, data potensi wisata, dan sumber daya pertanian. Semua data ini diambil di Pesisir Pantai Selatan DIY. Proses pengumpulan data didapatkan secara langsung (data primer) dengan cara mendatangi lokasilokasi yang telah ditentukan.

Pengumpulan data dilakukan di kawasan Pesisir Pantai Selatan DIY yang membentang sepanjang $113 \mathrm{~km}$. Proses pengumpulan data dilakukan dengan melakukan inventarisasi, identifikasi, dan analisis ekonomi di sepanjang wilayah pesisir pantai. Lebih spesifik lagi, penelitian dilakukan di beberapa lokasi yang sangat berpengaruh atau berpotensi menjadi kawasan ekonomi (kawasan pelabuhan perikanan, tempat budidaya udang atau tempat wisata).

Setelah semua data telah terkumpul, tahap selanjutnya dari metode ini adalah Design. Perancangan sistem dibuat menggunakan Unified Modeling Language (UML) yaitu, flowchart dan use case diagram.

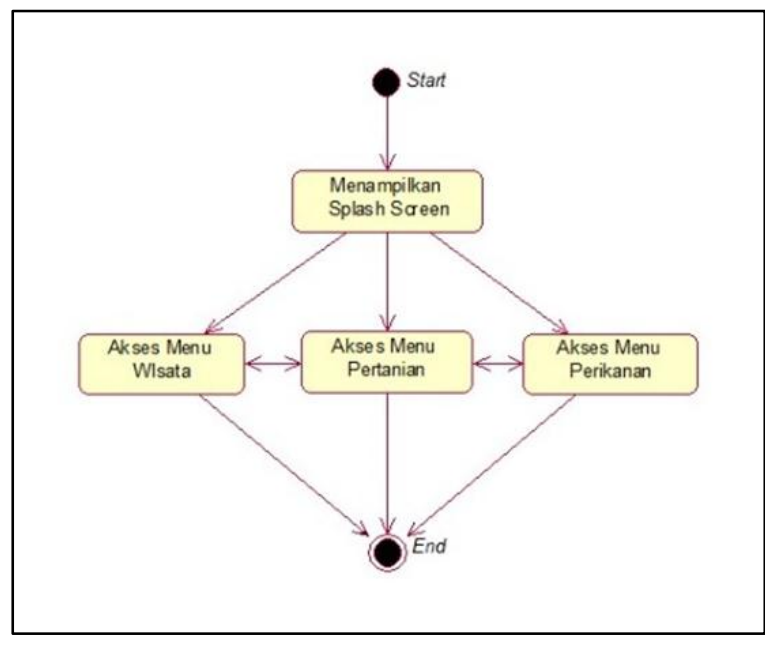

Gambar 3 Flowchart sistem 
Gambar 3 menampilkan flowchart atau diagram alir bagaimana sistem akan berjalan. Ketika sistem berjalan pertama kali akan menampilkan sebuah splash screen, selanjutnya sistem akan menampilkan tiga menu utama yang nantinya dipilih sesuai dengan keinginan pengguna.

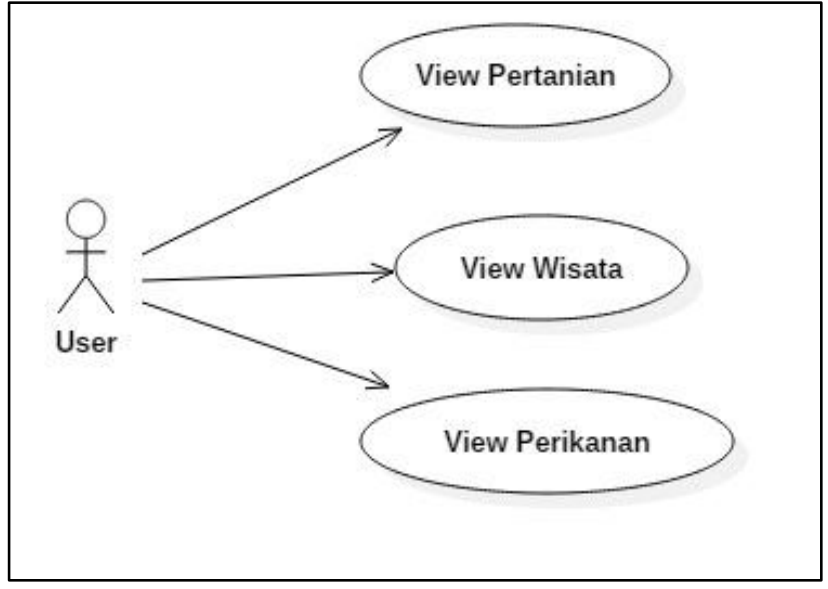

Gambar 4 Use Case Diagram Sistem

Gambar 4 menampilkan use case diagram sistem yang menunjukkan satu aktor utama, yaitu pengguna aplikasi. Pengguna aplikasi dapat melihat tiga menu utama yang telah disediakan sistem, yaitu menu Pertanian, menu Wisata, dan menu Perikanan. Berdasarkan use case diagram, terlihat bahwa pengguna hanya dapat melihat informasi sesuai dengan menu yang dipilihnya.

Pada tahap Implementation akan dilakukan implementasi dari desain yang sudah dirancang sebelumnya. Proses implementasi ini akan menghasilkan sebuah aplikasi SIG yang akan dibangun menggunakan bahasa pemrograman Java dan diterapkan langsung ke dalam perangkat Android. Penjelasan lebih dalam akan dibahas lebih detail di Bab 4.

Tahap terakhir dalam penggunaan metode ini adalah Analyst. Tahap ini adalah tahap pengujian semua fitur dalam aplikasi dengan menggunakan dua metode yang berbeda. Metode yang pertama adalah metode Blackbox. Blackbox adalah metode yang dilakukan untuk mengetahui apakah ada kesalahan pada setiap fitur yang telah dibuat. Metode Blackbox akan dilakukan sendiri oleh pihak pengembang. Metode yang kedua adalah Pengujian Beta (Beta Testing). Pengujian Beta adalah pengujian yang melibatkan calon pengguna aplikasi. Calon pengguna aplikasi akan langsung mencoba menggunakan aplikasi yang dibuat. Setelah itu, mereka akan menjawab beberapa pertanyaan dalam bentuk kuesioner. Jawaban dari mereka akan diolah agar terlihat apakah mereka sudah puas dengan aplikasi yang telah dibuat.

\section{Hasil dan Pembahasan}

Bab ini akan menjelaskan secara detail dari tahapan Implementation dari tahapan penelitian yang telah dijelaskan sebelumnya. Lebih spesifik lagi, bab ini akan menjelaskan proses pembuatan aplikasi SIG secara terperinci.

Fitur utama dari aplikasi ini untuk menampilkan informasi persebaran sumber daya alam pada Pesisir Pantai Selatan dari menu yang sudah disediakan. Selain itu, aplikasi ini dapat digunakan sebagai media pengawasan, sehingga pengguna dapat melihat perkembangan sumber daya alam pada setiap daerah di Pesisir Pantai Selatan. Pengguna dapat memanfaatkan fitur tampil data pada aplikasi ini untuk mengolah data lebih lanjut tentang sumber daya kelautan sekaligus memaksimalkan data persebaran tempat wisatanya. Kemampuan aplikasi yang terbatas pada menampilkan informasi bertujuan agar aplikasi nantinya dapat dipergunakan secara mudah dan efektif.

Sesuai dengan yang dijelaskan pada tahap Design, SIG ini mempunyai tiga menu utama, yaitu: Menu Wisata, Menu Pertanian, dan Menu Perikanan.

Pada bagian Menu Wisata, pengguna dapat melihat sebaran objek-objek wisata yang berada pada Pesisir Pantai Selatan. Semua objek wisata akan ditunjukkan dalam bentuk marker berwarna merah di dalam peta. Proses menampilkan marker ini memanfaatkan layanan dari 
Google Map API khususnya dalam menentukan posisi marker serta menampilkannya ke dalam peta. Selain itu, pengguna juga dapat memperbesar atau memperkecil (zoom) gambar peta. Hal ini akan menambah akurasi dari informasi yang akan didapatkan pengguna.

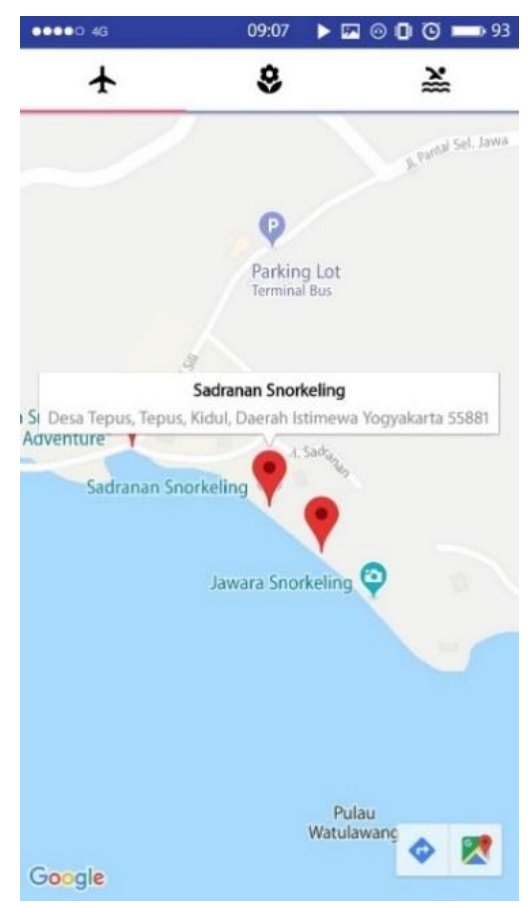

Gambar 5 Menu Wisata

Gambar 5 adalah halaman Menu Wisata. Google Map API dipakai untuk menampilkan peta serta marker yang menjelaskan lokasi serta potensi wisata yang ada di sebuah lokasi. Ketika pengguna melakukan aksi tap pada marker, maka akan muncul sebuah informasi tambahan terkait pariwisata di tempat tersebut. Selain itu, dengan digunakannya Google Map API, di bagian kanan bawah juga tersedia fitur Direction. Fitur ini memungkinkan pengguna untuk mencari jalan menuju tempat wisata.

Pada bagian Menu Pertanian akan menampilkan data-data yang diperoleh mengenai persebaran panen sektor pertanian di Pesisir Pantai Selatan. Tampilan pada menu ini tidak jauh berbeda dengan Menu Wisata, perbedaannya hanya pada warna marker yang digunakan. Pada Menu Pertanian, warna marker yang digunakan adalah warna biru. Gambar 6 menunjukkan tampilan dari Menu Pertanian. 


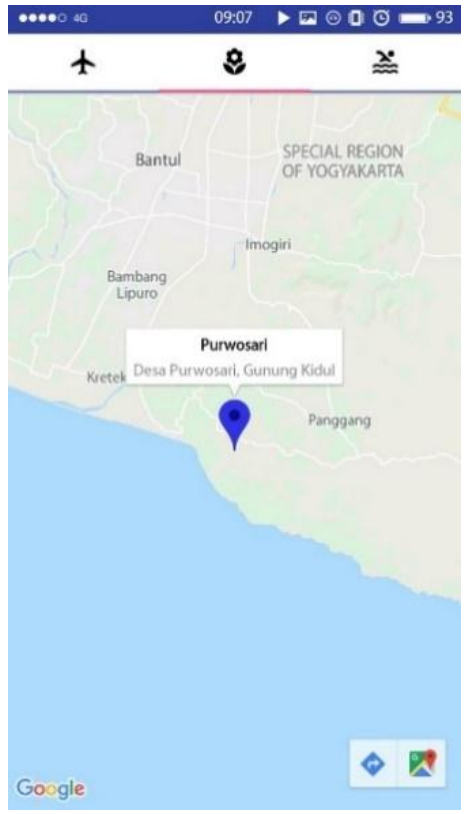

Gambar 6 Menu Pertanian

Selain dapat melihat persebaran tempat panen, pada Menu Pertanian juga akan dapat menampilkan informasi tambahan tentang tanaman-tanaman apa yang menjadi komoditas utama di daerah tersebut. Informasi ini ditampilkan dalam bentuk grafik yang didapatkan dari halaman web server.

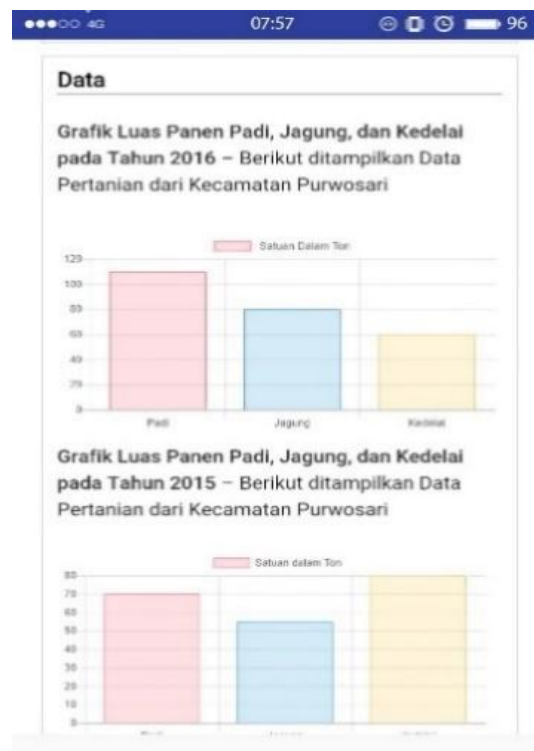

Gambar 7 Contoh Informasi Tambahan

Gambar 7 merupakan tampilan dari data pertanian dan perikanan. Data dalam bentuk grafik ini akan muncul ketika pengguna melakukan tap pada marker yang tersedia di menu Perikanan dan Pertanian. Pengguna dapat melihat data mengenai persebaran sumber daya alam berdasarkan data yang telah dikumpulkan sebelumnya.

Tidak jauh berbeda dengan Menu Pertanian, Menu Perikanan juga memiliki tampilan yang sama. Perbedaan utama terletak pada data dan warna marker yang ditampilkan. Menu Perikanan akan berisikan data-data mengenai persebaran sumber daya sektor perikanan yang terdapat pada Pesisir Pantai Selatan, sedangkan warna marker yang digunakan adalah warna hijau. Gambar 8 menunjukkan tampilan dari Menu Perikanan. 


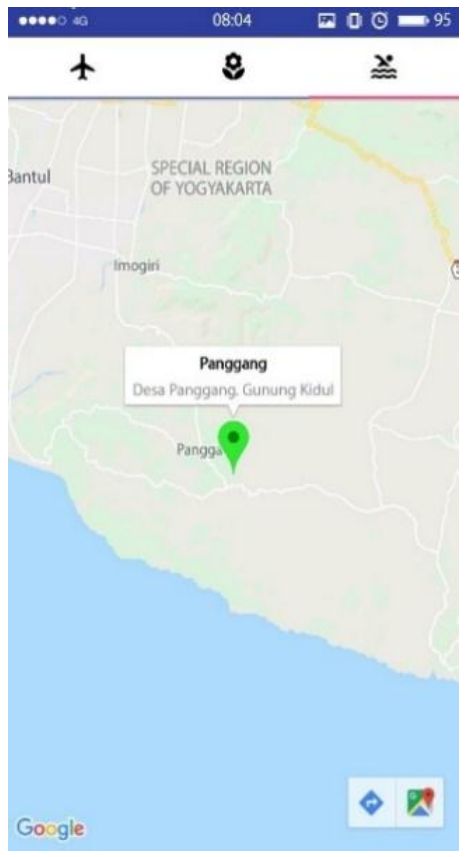

Gambar 8 Menu Perikanan

Tahapan selanjutnya adalah pengujian sistem. Seperti yang telah disebutkan sebelumnya, pengujian menggunakan metode Blackbox yang digunakan untuk menguji semua fungsi yang telah dibuat dalam sistem. Pengujian dilakukan oleh pengembang aplikasi yang bertujuan untuk mencari cacat atau kesalahan sistem sebelum diserahkan ke pelanggan. Hal ini dilakukan agar dapat diketahui sebaik apa sistem yang telah dibuat.

Tabel 1. Hasil Pengujian Sistem

\begin{tabular}{|c|c|c|c|c|}
\hline $\begin{array}{c}\text { Skenario yang } \\
\text { diuji }\end{array}$ & Kondisi & $\begin{array}{c}\text { Luaran yang } \\
\text { diharapkan }\end{array}$ & $\begin{array}{c}\text { Luaran dari } \\
\text { sistem }\end{array}$ & $\begin{array}{c}\text { Status } \\
\text { Pengujian }\end{array}$ \\
\hline $\begin{array}{l}\text { Menampilkan } \\
\text { splash screen }\end{array}$ & $\begin{array}{l}\text { Buka } \\
\text { aplikasi }\end{array}$ & $\begin{array}{l}\text { Menampilkan layar } \\
\text { awal dan logo SIG }\end{array}$ & $\begin{array}{c}\text { Menampilkan } \\
\text { layar awal dan } \\
\text { logo SIG }\end{array}$ & Sesuai \\
\hline $\begin{array}{l}\text { Menampilkan } \\
\text { Informasi Wisata }\end{array}$ & $\begin{array}{l}\text { Pilih menu } \\
\text { wisata }\end{array}$ & $\begin{array}{c}\text { Menampilkan } \\
\text { menu Wisata }\end{array}$ & $\begin{array}{l}\text { Menampilkan } \\
\text { menu Wisata }\end{array}$ & Sesuai \\
\hline $\begin{array}{l}\text { Menampilkan } \\
\text { Informasi } \\
\text { Perikanan }\end{array}$ & $\begin{array}{l}\text { Pilih menu } \\
\text { perikanan }\end{array}$ & $\begin{array}{l}\text { Menampilkan } \\
\text { menu Perikanan }\end{array}$ & $\begin{array}{l}\text { Menampilkan } \\
\text { menu Perikanan }\end{array}$ & Sesuai \\
\hline $\begin{array}{l}\text { Menampilkan } \\
\text { Informasi } \\
\text { Pertanian }\end{array}$ & $\begin{array}{l}\text { Pilih menu } \\
\text { pertanian }\end{array}$ & $\begin{array}{l}\text { Menampilkan } \\
\text { menu Pertanian }\end{array}$ & $\begin{array}{l}\text { Menampilkan } \\
\text { menu Pertanian }\end{array}$ & Sesuai \\
\hline
\end{tabular}

Berdasarkan Tabel 1, status dari setiap pengujian sudah dalam keadaan "sesuai". Hasil dari pengujian Blackbox adalah aplikasi sudah berjalan sesuai dengan yang diharapkan.

Tahapan selanjutnya adalah melakukan pengujian Beta. Pada penelitian ini, pengujian dilakukan menggunakan kuesioner yang diberikan kepada 30 orang responden. Setiap pertanyaan dari kuesioner akan dijawab oleh responden dengan memilih satu dari lima kemungkinan jawaban yaitu: Sangat Baik (5 poin); Baik (4 poin); Cukup (3 poin); Kurang (2 poin); dan Sangat Kurang (1 poin). Selanjutnya, skor akhir dari setiap pertanyaan kuesioner akan diolah lagi dengan persamaan yang ada pada Gambar 9.

$$
\text { Skor }=\sum(P \times F)
$$

Gambar 9 Persamaan untuk Menghitung Skor Akhir Setiap Pertanyaan 
Gambar 9 dapat dijelaskan sebagai berikut: "P" merupakan poin dari pilihan jawaban responden; sedangkan, "F" merupakan frekuensi kemunculan dari pilihan jawaban responden. Selanjutnya, skor akhir setiap pertanyaan adalah jumlah dari hasil perkalian "P" dengan "F" dari masing-masing kategori poin.

Tabel 2. Hasil Kuesioner

\begin{tabular}{|c|c|c|c|c|c|c|}
\hline Pertanyaan & 5 & 4 & 3 & 2 & 1 & Skor \\
\hline $\begin{array}{l}\text { Apakah informasi yang dimiliki aplikasi } \\
\text { mudah dimengerti? }\end{array}$ & 9 & 11 & 6 & 4 & 0 & 115 \\
\hline $\begin{array}{l}\text { Apakah aplikasi dapat menampilkan peta } \\
\text { dengan jelas? }\end{array}$ & 10 & 13 & 5 & 2 & 0 & 121 \\
\hline Apakah ukuran teks pada aplikasi jelas? & 10 & 15 & 5 & 0 & 0 & 125 \\
\hline $\begin{array}{l}\text { Apakah menu Wisata dapat diakses dengan } \\
\text { mudah? }\end{array}$ & 14 & 14 & 2 & 0 & 0 & 132 \\
\hline $\begin{array}{l}\text { Apakah menu Pertanian dapat diakses } \\
\text { dengan mudah? }\end{array}$ & 13 & 9 & 8 & 0 & 0 & 125 \\
\hline $\begin{array}{l}\text { Apakah menu Perikanan dapat diakses } \\
\text { dengan mudah? }\end{array}$ & 12 & 9 & 7 & 2 & 0 & 121 \\
\hline Apakah marker sudah tampil dengan jelas? & 15 & 7 & 8 & 0 & 0 & 127 \\
\hline Apakah aplikasi mudah dipahami? & 13 & 13 & 4 & 0 & 0 & 129 \\
\hline Apakah aplikasi sudah stabil? & 11 & 13 & 6 & 0 & 0 & 125 \\
\hline Apakah aplikasi sudah sesuai dengan tujuan? & 11 & 12 & 7 & 0 & 0 & 124 \\
\hline Jumlah Skor & & & & & & 1244 \\
\hline
\end{tabular}

Tabel 2 adalah rangkuman dari proses pencarian nilai skor akhir dari setiap pertanyaan yang telah dijawab oleh 30 responden yang dipilih. Berdasarkan hasil pengolahan kuesioner, didapatkan bahwa SIG yang dibuat mendapatkan jumlah skor akhir sebesar 1244 dari sepuluh pertanyaan yang diajukan. Selanjutnya, hasil dari kuesioner ini akan diolah dan dicocokkan kategori penilaiannya menggunakan Skala Likert. Skala Likert sendiri membutuhkan sebuah indikator variabel yang digunakan sebagai tolak ukur penyusunan pertanyaan-pertanyaan [16], [17] dan digambarkan secara detail pada Tabel 3.

Tabel 3. Skala Peringkat

\begin{tabular}{lcc}
\hline No. & Persentase Jawaban & Skala \\
\hline 1 & $80,07 \%-100 \%$ & Sangat Baik \\
2 & $60,07 \%-80 \%$ & Baik \\
3 & $40,07 \%-60 \%$ & Cukup \\
4 & $20,07 \%-40 \%$ & Kurang \\
5 & $0 \%-20 \%$ & Sangat Kurang \\
\hline
\end{tabular}

Berdasarkan Tabel 2, jumlah skor akhir yang didapatkan aplikasi SIG adalah 1244. Skor akhir ini akan diolah lagi guna mendapatkan nilai persentase kegunaan aplikasi. Nilai persentase kegunaan aplikasi didapatkan dengan cara Jumlah Skor Akhir/Skor Maksimum x 100\% atau $1244 / 1500 \times 100 \%=82,93 \%$. Nilai persentase kegunaan aplikasi ini kemudian akan dicocokkan dengan Tabel 3 untuk melihat aplikasi yang dibuat masuk ke dalam kategori apa. Berdasarkan hasil pengolahan kuesioner, didapatkan bahwa aplikasi SIG yang dibuat sudah masuk ke dalam golongan "Sangat Baik".

\section{Kesimpulan}

Kesimpulan dari penelitian yang telah dilakukan adalah Google Map API dapat digunakan untuk membangun SIG Potensi Sumber Daya Kelautan. SIG dapat menampilkan informasi yang lebih detail tidak hanya melalui marker saja, tetapi dapat melalui informasi- 
informasi tambahan. SIG ini dapat dikategorikan sebagai aplikasi yang "Sangat Baik" dibuktikan dengan tingkat kepuasan pengguna yang mendapatkan skor 82,93\%.

Penelitian dan pengembangan lebih lanjut perlu ditambahkan keterangan lebih lengkap pada setiap marker yang tersedia berikut dengan tampilan data yang lebih dinamis. Harapannya, dengan itu masyarakat akan mendapatkan informasi yang lebih terperinci lebih cepat. Selain itu, perlu adanya fitur-fitur tambahan seperti manajemen data sumber daya yang dapat dilakukan langsung melalui aplikasi.

\section{Daftar Pustaka}

[1] E. Roza, "Maritim Indonesia, Kemewahan Yang Luar Biasa," Kementrian Kelautan dan Perikanan Republik Indonesia, $1 \quad 9 \quad 2017 . \quad$ [Online]. Available: http://www2.kkp.go.id/artikel/2233-maritim-indonesia-kemewahan-yang-luar-biasa. [Accessed 232 2020].

[2] P. Subardjo, "Uji Kerawanan Terhadap Tsunami Dengan Sistem Informasi Geografis (SIG) Di Pesisir Kecamatan Kretek Kabupaten Bantul Yogyakarta.," Jurnal Kelautan Tropis, p. 82-97, 2015.

[3] L. Sahubawa, "Kajian Sebaran Potensi Ekonomi Sumber Daya Kelautan di Pantai Selatan Daerah Istimewa Yogyakarta sebagai Upaya Percepatan Investasi," Jurnal Teknosains, pp. 101-198, 2015.

[4] K. D. Hartomo, E. Sediyono, S. Y. J. Prasetyo and B. H. Simanjuntak, "Updated Pranata Mangsa: Recombination of Local Knowledge and Agro Meteorology using Fuzzy Logic for Determining Planting Pattern," IJCSI International Journal of Computer Science Issues, vol. 9, no. 6, pp. 367-372, 2012.

[5] StatsCounter, "Desktop vs Mobile," StatCounter, 20 January 2019. [Online]. Available: http://gs.statcounter.com/platform-market-share/desktop-mobile-tablet. [Accessed 11 July 2019].

[6] Y. A. Susetyo, P. O. N. Saian and R. Somya, "Pembangunan Sistem Informasi Zona Potensi Sumber Daya Kelautan Kabupaten Gunungkidul Berbasis HMVC Menggunakan Google Maps API dan JSON," Indonesian Journal of Computing and Modeling, vol. 1, no. 2, pp. 101-107, 2018.

[7] Y. Bustomi, M. A. Ramdhani and R. Cahyana, "Rancang Bangun Sistem Informasi Geografis Sebaran Tempat Riset Teknologi Informasi Di Kota Garut," Junal Algoritma Sekolah Tinggi Teknologi Garut, vol. 9, no. 1, pp. 171-177, 2012.

[8] I. B. Y. Adnyana and R. Effendi, "Rancang Bangun Sistem Informasi Geografis Persebaran Lokasi Obyek Pariwisata Berbasis Web dan Mobile Android (Studi Kasus di Dinas Pariwisata Kabupaten Gianyar)," Jurnal Teknologi Informasi dan Komunikasi, vol. 5, no. 1, pp. 9-16, 2014.

[9] F. Masykur, "IMPLEMENTASI SISTEM INFORMASI GEOGRAFIS MENGGUNAKAN GOOGLE MAPS API DALAM PEMETAAN ASAL MAHASISWA," Jurnal Teknik Industri, Mesin, Elektro dan Ilmu Komputer, vol. 5, no. 2, pp. 181-186, 2014.

[10] F. Mahdia and F. Noviyanto, "PEMANFAATAN GOOGLE MAPS API UNTUK PEMBANGUNAN SISTEM INFORMASI MANAJEMEN BANTUAN LOGISTIK PASCA BENCANA ALAM BERBASIS MOBILE WEB (Studi Kasus : Badan Penanggulangan Bencana Daerah Kota Yogyakarta)," Jurnal Sarjana Teknik Informatika, vol. 1, no. 1, pp. 162-171, 2014.

[11] S. Rachmawati, "Perancangan Aplikasi Android untuk Absensi Kepegawaian," 2015.

[12] Google Inc, 12 July 2016. [Online]. Available: http://developers.google.com/maps.

[13] E. Irwansyah, Sistem Informasi Geografis: Prinsip Dasar dan Pengembangan Aplikasi, 
Yogyakarta: Digibooks, 2013.

[14] F. Nugraha, "Metode Pengembangan Aplikasi Secara Cepat dan Adaptif Menggunakan Agile Software Development (Online)," 20 Oktober 2018. [Online]. Available: https://teknojurnal.com/metode-pengembangan-aplikasi-secara-cepat-dan-adaptifmenggunakan-agile-software-development/.

[15] C. Edeki, "Agile Software Development Methodology," European Journal of Mathematics and Computer Science, vol. 2, no. 1, pp. 22-27, 2015.

[16] S. Aronoff, Geographic Information System a Management Perspective, Ottawa: WDL Publication, 1989.

[17] A. Joshi, S. Kale, S. Chandel and D. K. Pal, "Likert Scale: Explored and Explained," British Journal of Applied Science \& Technology, vol. 7, no. 4, pp. 396-403, 2015. 